時系列 MSS に基づく栈橋 RC 床版の補修計画最適化手法の提案 +

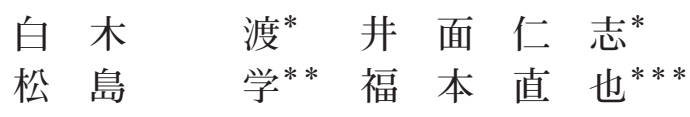

\title{
An Optimization Approach of Repair Plan of RC Slab of Piled Pier Using Time Series MSS
}

by

\author{
Wataru Shiraki ${ }^{*}$, Hitoshi Inomo *, Manabu Matsushima ${ }^{* *}$ and Naoya Fukumoto ***
}

\begin{abstract}
The maintenance of structures must be carried out periodically according to the performance degradation. The change of performance of structural system happens with multiple states including partial failures according to the passage of time. Such a system is known as a MSS (Multi-state system). Taking account of the appropriate maintenance of a MSS structural system with performance degradation, the reliability evaluation approach considering the time series MSS should be used.

In this study, an optimization approach of repair plan of RC slab of piled pier is proposed by the reliability evaluation method of time series MSS. Specifically, the performance degradation due to salt damage is considered and modeled by a time series MSS, and some optimal maintenance approaches proposed. Simultaneously, under the limit condition of a reliability evaluation index or the total repair expense, the safety and life cycle cost of the repair plan were compared using repair expense and a reliability assessment result. The costs of repairs are calculated and repair plans can be optimized.
\end{abstract}

Key words : Time series Multi-State System, RC slab of piled pier, Salt damage, Optimal repair plan

\section{1 緒 言}

塩害を受ける鉄筋コンクリート $(\mathrm{RC})$ 構造物は，その コンクリートの性状と構造物を取り巻く環境など様々な 不確定要因が複雑に関係して劣化していく，そのため， 塩害を受ける $\mathrm{RC}$ 構造物の維持管理業務は，これらの塩 害劣化の不確定要因を把握した上で構造物の性能劣化予 測・信頼性評価を行って実施されるべきである。また， 昨今の不安定な経済情勢下において, 既存構造物の維持 管理負担の削減も求められており, 既設構造物の性能評 価を適切に行うとともに，ライフサイクルコスト (LCC) を最小化する補修計画の立案を可能にするシステム開発 が求められている.

阪神淡路大震災以降，地震等による外力が構造物の要 求性能を超えない確率（信頼度）を尺度とした信頼性設 計法の導入が検討されるようになった。しかし，構造物 の性能がそれを取り巻く外部環境の変化とともに時間経 過に伴って劣化するのに対し, 従来の信頼性設計法では, 性能の時間的劣化を考慮の難しさもありその導入は遅れ ている。また，信頼性の評価においては，時間の経過と 共に多段階に変化する性能劣化の状況を考慮する手法の 開発が遅れていた。それゆえ，著者らは時間的に多段階 に変化する構造物の性能を設計段階で一括して評価する
手法として, 多状態性能を有するシステム (Multi-State System：以下 MSS と略す) ${ }^{1)} の$ 信頼性評価手法用いて, 橋梁構造物の信頼性評価手法の開発を行ってきた.2), 3)

本研究では，被害が深刻化してきている塩害を受ける 鉄筋コンクリート栈橋上部工の床版（以下 $\mathrm{RC}$ 床版と略） を対象として, その塩害劣化予測並びに信頼性評価を， 時系列を考慮した MSS の信頼性評価手法を用いて行う. その評価結果を踏まえて, 補修費用を最適化するための 補修計画について検討する.

\section{$2 \cdot 1$ MSS の基本概念}

\section{2 時系列 MSS}

すべてのシステム, 構造物等は与えられた環境下で意 図された性能を発揮できるように設計される。性能はシ ステムを構成する要素の劣化や外部環境の変化により， 使用期間中に常に同じ性能を示すとは限らず，異なる性 能を有することになる。このような有限個の性能值を有 するシステムを MSS と呼ぶ. MSS において, $k_{j}$ 個の性 能を有する任意のシステム要素 $j$ の性能值 $g_{j}$ は式 (1)で 表される。 また，任意の時刻におけるシステム要素 $j$ の 状態確率 $p_{j}(\mathrm{t})$ は, 式 (2)で表される。

$$
\begin{aligned}
& g_{j}=\left\{g_{j 1}, g_{j 2}, \cdots, g_{j k_{j}}\right\} \\
& p_{j}(t)=\left\{p_{j 1}(t), p_{j 2}(t), \cdots, g_{j k_{j}}(t)\right\}
\end{aligned}
$$

$\dagger \quad$ 原稿受理 平成 25 年 6 月 4 日 Received June 4,2013 @ 2014 The Society of Materials Science, Japan

* 正会員 香川大学工学部信頼性情報システム工学科７ 761-0396 高松市林町, Dept. of Reliability-based Information Systems Eng., Kagawa Univ., Hayashi-cho, Takamatsu, 761-0396

** 正 会員 香川大学工学部安全システム工学科７761-0396 高松市林町, Dept. of Safety systems Construction Eng., Faculty of Eng., Kagawa Univ., Hayashi-cho, Takamatsu, 761-0396

***＼cjkstart高菱エンジニアリング(株)＝676-0008＼cjkstart高砂市新井, KORYO ENGINEERING CO., LTD, Arai, Takasago, 676-0008 
一般に，システムの性能は劣化と補修により変化し， それぞれの推移率は式 (3)で表される.

$$
\lambda=1 / M T T F, \quad \mu=1 / M T T R
$$

ここで, $M T T F$ は平均故障時間, $M T T R$ は平均補修時 間間隔である. Fig. 1 に示されるような時間経過に伴う 性能劣化打よび補修によるシステムの状態移行をマルコ フ過程でモデル化すれば，式 (4)の微分方程式が成立し， 時刻 $t$ での各状態確率 $p_{j}(t)$ が求められる. ${ }^{1)}$

$$
\left\{\begin{array}{l}
\frac{d p_{k}(t)}{d t}=\sum_{e=1}^{k-1} \mu_{e, k} p_{e}(t)-p_{k}(t) \sum_{e=1}^{k-1} \lambda_{k, e} \\
\frac{d p_{i}(t)}{d t}=\sum_{e=i+1}^{k-1} \lambda_{e, i} p_{e}(t)+\sum_{e=1}^{i-1} \mu_{e, i} p_{e}(t)-p_{i}(t)\left(\sum_{e=1}^{i-1} \lambda_{i, e}+\sum_{e=i+1}^{k} \mu_{i, e}\right) \quad(1<i<k) \\
\frac{d p_{1}(t)}{d t}=p_{k}(t) \sum_{e=2}^{k} \lambda_{e, 1}-\sum_{e=2}^{k} \mu_{1, e} p_{1}(t)
\end{array}\right.
$$

\section{$2 \cdot 2$ MSS の信頼性評価手法}

MSS の信頼性の指標として，式 (5)〜 (7) で定義される アベイラビリティ $A(t)$, 性能期待值 $E_{t}$, 性能不足值 $D_{t}$ が用いられる.1

$$
\begin{aligned}
& A(t)=\sum_{k=1}^{K} p_{k}(t) 1\left(p_{k} \geq w\right) \\
& E_{t}=\sum_{k=1}^{K} p_{k}(t) g_{k} \\
& D_{t}=\sum_{k=1}^{K} p_{k}(t) \max \left(w-g_{k}, 0\right)
\end{aligned}
$$

ここで,アベイラビリティ $A(t)$ は任意の時刻においてシス テムの性能が要求以上となる状態確率の合計值, 性能期 待值 $E_{t}$ は任意の時刻においてシステムが発揮する瞬間出 力性能の期待值, 性能不足值 $D_{t}$ はシステムの性能が要求 性能に達していない場合に, どの程度要求性能から不足が 生じているかを表す瞬間性能偏差の期待值のことである.

\section{3 塩害劣化予測}

\section{$3 \cdot 1$ 塩害による劣化の進行過程}

本研究では, Fig. 2 に示すように, 塩害による RC 構 造物の性能劣化に 3 段階の劣化の進行過程があると考え た。第 1 段階の潜伏期は，かぶり位置における塩化物イ オン濃度が腐食発生限界濃度に達するまでの期間である。 第 2 段階の進展期は，鉄筋の腐食が進み，腐食量が腐食 ひび割れ発生腐食量に達するまでの期間である。第 3 段 階の加速期は，ひび割れが発生し鉄筋の腐食速度がさら に加速する期間であり，急激な耐力低下を引き起こし， 最終的には耐力㳖失に至る可能性がある期間である。ま た，塩害劣化モデルと加速期 $\mathrm{RC}$ 構造物の耐力が若干低 下した状態を考慮すると， RC 床版の性能はTable 1 に

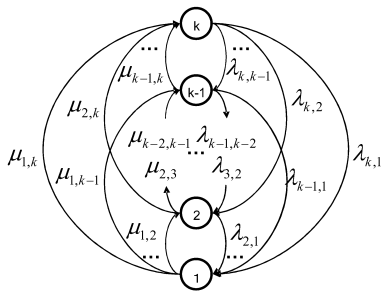

Fig. 1 State-space diagram for repairable system.

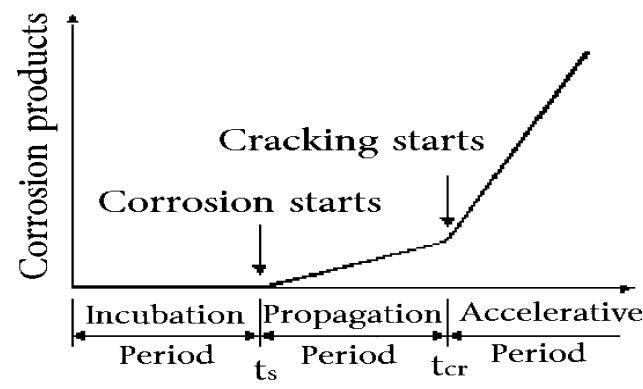

Fig. 2 The model of the salt damage degradation.

Table 1 State of RC slab of five performances.

\begin{tabular}{|c|c|c|c|c|}
\hline State5 & State4 & State3 & State2 & State1 \\
\hline $\begin{array}{c}\text { Initial } \\
\text { State }\end{array}$ & $\begin{array}{c}\text { Corrosion } \\
\text { initiation }\end{array}$ & $\begin{array}{c}\text { Cracking } \\
\text { initiation }\end{array}$ & $\begin{array}{c}\text { Decline } \\
\text { carrying } \\
\text { capacity }\end{array}$ & $\begin{array}{c}\text { Lost } \\
\text { carrying } \\
\text { capacity }\end{array}$ \\
\hline
\end{tabular}

示すように，時系列的に 5 つの状態をとることになる.

本研究では，状態 5 を建設当初，状態 4 を腐食が開始 した状態，状態 3 をひび割れが発生した状態，状態 2 を 耐力が若干低下した状態, 状態 1 を耐力喪失状態とする.

\section{$3 \cdot 2$ 塩害劣化モデル}

\section{1）潜伏期}

腐食開始時間は，塩化物イオンの拡散予測により，か ぶり位置での塩化物イオン量が腐食限界塩化物イオン量 に達する時期として推定する。外部環境からコンクリート 中へ塩化物イオン量が浸透していく状態は式 (8)のフィッ クの拡散方程式によって表される。ただし，式 (8)にお いて塩化物イオンのコンクリート内への浸透は一定とす る。かぶり位置での塩化物イオン量 $C(X, t)$ が腐食発生 限界塩化物イオン量 $C_{\alpha}$ に達すると鉄筋の腐食が開始す ると考え，その時期を $t_{1}$ とする。

$C(X, t)=C^{\prime}+W \cdot\left[2 \sqrt{\frac{t}{\pi D}} \cdot \exp \left(-\frac{X^{2}}{4 D t}\right)-\frac{X}{D}\left\{1.0-e r f\left(\frac{X}{2 \sqrt{D t}}\right)\right\}\right]$

ここで, $C(X, t)$ は深さ $X(\mathrm{~cm})$, 経過時間 $t$ (年)における 塩化物イオン濃度 $\left(\mathrm{kg} / \mathrm{m}^{3}\right), C^{\prime}$ は初期含有塩化物イオン 濃度 $\left(\mathrm{kg} / \mathrm{m}^{3}\right), D$ は見かけの拡散係数 $\left(\mathrm{cm}^{2} / \mathrm{s}\right), \operatorname{erf}()$ は誤差関数, $W$ は付着塩分量である.

\section{2) 進展期}

進展期の長さは腐食速度から推定可能である。コンク リート中の鉄筋の腐食速度は，コンクリート品質や外部 環境等によって変化する。そこで，ニューラルネットワー クを用い，現場で計測できる項目をもとに，式 (9)で表 される回帰式 ${ }^{4)}$ から腐食速度 $R(T, C, D)$ を推定する.

$$
R(T, C, D)=0.27 \times\left(21.33 \times C_{T}(T) \times C_{C}(C)\right)^{1.38} \cdot C_{D}(D)
$$

ただし，この回帰式は気温とかぶり位置での塩化物イオ ン濃度，コンクリートの品質のそれぞれが腐食速度に与 える影響を考慮し，3つの入力項目から構築され，それ らの影響值 ${ }^{4}$ は式 (10) と式 (11), 式 (12)で表される.

$$
\begin{aligned}
& C_{T}(T)=\exp \{-2.593 \cdot(1000 \cdot 1 / K)+8.695\} \\
& C_{C}(C)=1.93 \sqrt{1.0-\frac{(C-12.0)^{2}}{\left(12.0-C_{c r}\right)^{2}}}
\end{aligned}
$$




$$
C_{D}(D)=0.1129 \cdot\left(D_{t} \cdot \frac{0.419}{t^{-0.54}}\right)
$$

ここで， $K$ は温度 $(K=T+273.15) ， C$ はかぶり位置での 塩化物イオン濃度 $\left(\mathrm{kg} / \mathrm{m}^{3}\right), C_{c r}$ は限界塩化物イオン濃 度 $\left(\mathrm{kg} / \mathrm{m}^{3}\right), t$ は経過年数 (年), $D_{t}$ は経過年数 $t$ 年時点 での塩化物イオンの見かけの拡散係数 $\left(\mathrm{cm}^{2} / \mathrm{s}\right)$ である.

腐食量 $\Delta$ は腐食が開始してからの時間で腐食速度を積 分したものとし，式 (13)で表される.5)ただし，潜伏期で は腐食が開始していないため腐食量はゼロである.

$$
\Delta=\int_{\mathrm{t}_{1}}^{t_{2}} R(T, C, D)
$$

腐食ひび割れ発生時の限界腐食量 $M_{c r}$ は，かぶり $C_{o}$ と鉄筋径 $\phi$ の関係式 5) 用いて式 (14)で表される。そし て，腐食量が腐食ひび割れ発生腐食量 $M_{c r}$ に達した時に ひび割れが発生すると考え，その時期を $t_{2}$ とする.

$$
M=44.22\left(C_{a} / \phi\right)^{0.7206}
$$

\section{3) 加速期}

加速期では，ひび割れの発生によって，進展期以前に 比べて塩化物イオンや溶存酸素を含んだ水が鉄筋と接し やすくなるため，鉄筋がより腐食されやすくなる，そこ で本研究では, 加速期での腐食速度を進展期での腐食速 度の 3.7 倍とする.

$$
R_{a}=\frac{A_{S}-A_{S}^{\prime}}{A_{S}} \times 100
$$

ここで, $R_{a}$ は断面減少率 $(\%), A_{s}$ は腐食前の鉄筋断面 積 $\left(\mathrm{cm}^{2}\right), A_{s}$ 'は腐食後の鉄筋断面積 $\left(\mathrm{cm}^{2}\right)$ である.

一般に，鉄筋コンクリートの鉄筋断面減少率が $20 \%$ に 達すると，終局耐力が急激に低下すると考えられている. 鉄筋腐食劣化水準は劣化グレード ${ }^{5)}$ にって表され，劣 化グレードが 3 のとき断面減少率が $1 \%$ ，グレード 4 のと き $5 \%$, グレード 5 のとき $20 \%$ となる. 鉄筋の腐食が進む につれて，鉄筋とコンクリートをつなぐ付着力が低下し， グレート 5 では付着力がほぼゼロとなり, 鉄筋コンクリー 卜は破壊状態になると考えられることから，本研究では， 断面減少率が $5 \%$ に達した時点を耐力低下時期とし， $20 \%$ に達した時点を耐力㳖失時期 $t_{4}$ とする.

\section{$4 \cdot 1$ 評価対象の諸元}

\section{4 時系列 MSS}

本研究では，塩害地域に多く建設される栈橋上部工の 床版 $(\mathrm{RC} \text { 床版 })^{5)}$ の塩害劣化を仮定した信頼性評価を行 う。塩害劣化の塩害予測の条件を Table 2 に示す。

\section{$4 \cdot 2 \mathrm{RC}$ 床版の性能劣化の確率モデル}

\section{1) 性能劣化率の推定}

Table 1 に示した RC 床版の性能状態が時間経過とと もに，状態 5 から状態 1 へと推移するには，Fig. 3 に示 すように各状態への性能劣化が生じる性能劣化率 $\lambda_{5,4}$, $\lambda_{4,3}, \lambda_{3,2}, \lambda_{2,1}$ が存在する.

本研究では, 100 年間のかぶり位置での塩化物イオン 濃度と腐食量, 断面減少率の変化を Fig. 4 から Fig. 6 に示すように，塩害劣化モデルに基づく 1 万回の塩害劣 化のモンテカルロシミュレーションからそれぞれ求めた。 この塩害劣化予測シミュレーションから，腐食開始時
期 $t_{1}$ は 21 年, ひび割れ発生時期 $t_{2}$ は 35 年，耐力低下時 期 $t_{3}$ は 41 年, 耐力喪失時期 $t_{4}$ は 65 年と推定できる。し たがって，それぞれの性能劣化確率は式 (16)から式 (19) を用いて算出される。

$$
\begin{aligned}
& \lambda_{5,4}=\frac{1}{t_{1}}\left[\text { year }^{-1}\right] \\
& \lambda_{4,3}=\frac{1}{t_{2}-t_{1}}\left[\text { year }^{-1}\right] \\
& \lambda_{3,2}=\frac{1}{t_{3}-t_{2}}\left[\text { year }^{-1}\right] \\
& \lambda_{2,1}=\frac{1}{t_{4}-t_{3}}\left[\text { year }^{-1}\right]
\end{aligned}
$$

\section{2) 性能値の推定}

本研究では, $t$ 年経過後における栈橋 $\mathrm{RC}$ 床版の断面 残存率を性能值として用いる。断面残存率とは，腐食に 対する鉄筋断面積の残存の程度を意味している．各性能

Table 2 Deterministic Design values and their statistical characteristic values of RC slab.

\begin{tabular}{|l|l|}
\hline $\begin{array}{l}\text { The amount of chloride ion initial } \\
\text { content }\left(\mathrm{kg} / \mathrm{m}^{3}\right)\end{array}$ & 0.798 \\
\hline Amount of adhesion salinity & $2.083 \times 10^{-9}$ \\
\hline Average of diffusion coefficient $\left(\mathrm{cm}^{2} / \mathrm{s}\right)$ & $1.608 \times 10^{-8}$ \\
\hline $\begin{array}{l}\text { Standard deviation of diffusion coefficient } \\
\left(\mathrm{cm}^{2} / \mathrm{s}\right)\end{array}$ & $6.432 \times 10^{-9}$ \\
\hline Covering $(\mathrm{mm})$ & 40.0 \\
\hline Diameter of reinforcement $(\mathrm{mm})$ & 15.9 \\
\hline Average yearly temperature $\left({ }^{\circ} \mathrm{C}\right)$ & 16.2 \\
\hline Rebar spacing $(\mathrm{cm})$ & 10 \\
\hline Unit mass of concrete $\left(\mathrm{kg} / \mathrm{m}^{3}\right)$ & 2100.0 \\
\hline Water cement ratio $(\%)$ & 54.3 \\
\hline Percentage of rainy days per year & 0.305 \\
\hline Useful lives $($ year $)$ & 100 \\
\hline
\end{tabular}

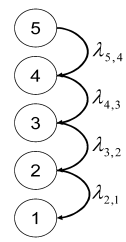

Fig. 3 The state space diagram of the RC slab.

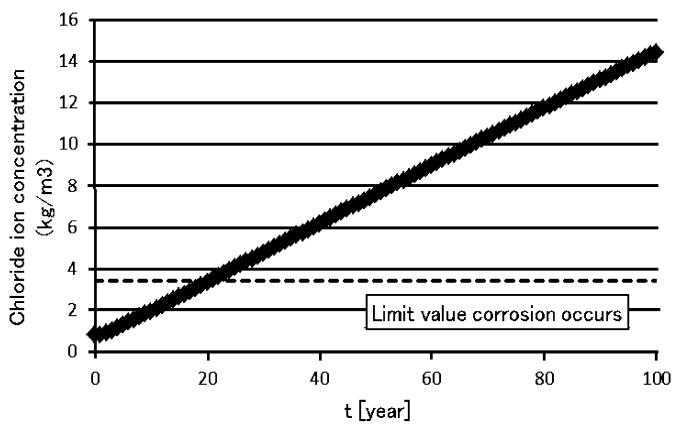

Fig. 4 Chloride ion concentration under covering. 


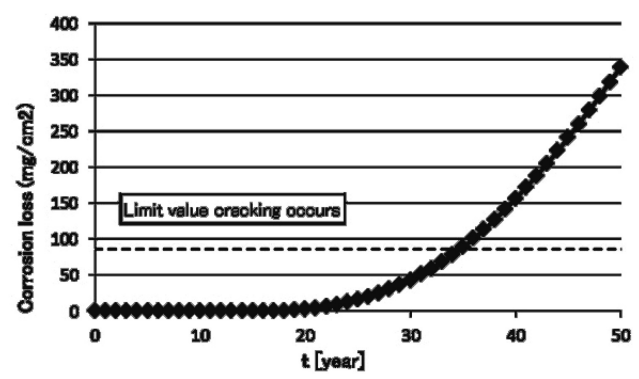

Fig. 5 Corrosion Loss.

状態での断面残存率は Fig. 6 で示した 100 年間の断面減 少率の変化から，それぞれTable 3 で示される。

したがって，栈橋 RC 床版の性能值は Table 4 に示す ように, 状態 5 の性能值は $g_{5}=100$, 状態 4 の性能值は $g_{4}=99.9$, 状態 3 の性能值は $g_{3}=97.2$, 状態 2 の性能值 は $g_{2}=94.6$, 状態 1 の性能值は $g_{1}=79.7$ となる.

\section{3) RC 床版の性能劣化の確率モデル}

これまでの塩害劣化予測シミュレーションから， RC 床 版の性能劣化の確率モデルを Fig. 7 に示す.

\section{$4 \cdot 3$ 性能状態確率の推定}

$\mathrm{RC}$ 床版の時刻 $t$ での各性能状態の状態確率 $p_{1}(\mathrm{t})$ $p_{5}(\mathrm{t})$ を求めるために, Fig. 7 に示す確率モデルにおける 各性能状態への性能劣化をマルコフ過程でモデル化する と, 式 (20)の微分方程式が成立する。

$$
\left\{\begin{array}{l}
\frac{d p_{5}(t)}{t}=-\lambda_{5,4} p_{5}(t) \\
\frac{d p_{4}(t)}{t}=\lambda_{5,4} p_{5}(t)-\lambda_{4,3} p_{4}(t) \\
\frac{d p_{3}(t)}{t}=\lambda_{4,3} p_{4}(t)-\lambda_{3,2} p_{3}(t) \\
\frac{d p_{2}(t)}{t}=\lambda_{3,2} p_{3}(t)-\lambda_{2,1} p_{2}(t) \\
\frac{d p_{1}(t)}{t}=\lambda_{2,1} p_{2}(t)
\end{array}\right.
$$

ここで， RC 床版の初期状態は建設当初の状態 5 で, 初期状態 $p_{5}(0)=1, p_{4}(0)=p_{3}(0)=p_{2}(0)=p_{1}(0)=0$ とし てこの微分方程式を解くと, 時刻 $t$ での各性能状態の状 態確率が算出される。その結果を Fig. 8 に示す.

\section{$4 \cdot 4$ 時系列 MSS による信頼性評価}

栈橋 RC 床版は断面減少率が $20 \%$ に達した状態 1 , つ まり，鉄筋の断面残存率が $80 \%$ まで低下した状態 1 で危 険となるので, 栈橋 $\mathrm{RC}$ 床版への要求性能を $W=80.0$ と

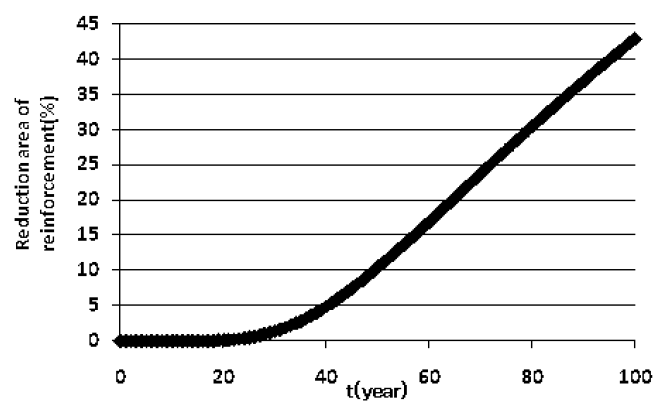

Fig. 6 Reduction area of reinforcement.
Table 3 Chloride ion concentration under covering.

\begin{tabular}{|c|c|c|c|c|c|}
\hline Number of state & 5 & 4 & 3 & 2 & 1 \\
\hline $\mathrm{t}($ year) & 0 & 21 & 35 & 41 & 65 \\
\hline Reduction in area (\%) & 0 & 0.1 & 2.8 & 5.4 & 20.2 \\
\hline Survival rate(\%) & 100 & 99.9 & 97.2 & 94.6 & 79.7 \\
\hline
\end{tabular}

Table 4 Performance value in each state.

\begin{tabular}{|c|c|c|c|c|c|}
\hline & $\mathrm{g}_{5}$ & $\mathrm{~g}_{4}$ & $\mathrm{~g}_{3}$ & $\mathrm{~g}_{2}$ & $\mathrm{~g}_{1}$ \\
\hline $\begin{array}{c}\text { Performance } \\
\text { value(\%) }\end{array}$ & 100 & 99.9 & 97.2 & 94.6 & 79.7 \\
\hline
\end{tabular}

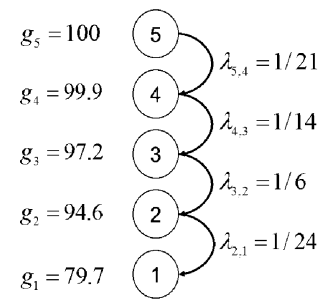

Fig. 7 State space diagram of performance deterioration of RC slab.

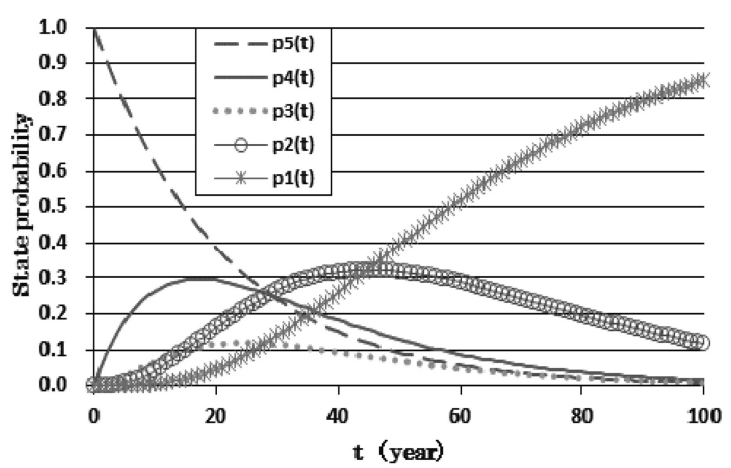

Fig. 8 State probabilities of RC slab.

し, 時系列 MSS による栈橋 RC 床版の信頼性評価を行う。 まず，アベイラビリティは，建設当初である状態 5 か ら耐力低下の状態 2 までが安全な状態となるので, 式 (5) を用いて，以下の式 (21)で求められる。

$$
A(t)=p_{5}(t)+p_{4}(t)+p_{3}(t)+p_{2}(t)
$$

性能期待值は式 (6)を用いて, 式 (22)で求められる. $E_{t}=100 p_{5}(t)+99.9 p_{4}(t)+97.2 p_{3}(t)+94.6 p_{2}(t)+79.7 p_{1}(t)$

性能不足值は式 (7)を用いて, 式 (23)で求められる。

$$
D_{t}=(80.0-79.7) p_{1}(t)
$$

また，従来の信頼性評価法では， RC 床版の断面減少 率が $20 \%$ に達した場合を限界状態として信頼性の評価を 行う。そこで， 1 万回の塩害劣化予測において，100 年 間のうち断面減少率が $20 \%$ を超える回数 $k$ をカウントし, 式 (24) から時刻 $t$ における破壊確率 $P_{f}(t)$ を算出する。そ して，その破壊確率を用いて式 (25)から，時刻 $t$ におけ る $\mathrm{RC}$ 床版の信頼度が算出できる.

$$
\begin{aligned}
& P_{f}(t) \cong \frac{k}{10000} \\
& R(t)=1-P_{f}(t)
\end{aligned}
$$


以上の塩害劣化予測シミュレーションから求められた 信頼度, アベイラビリティ, 性能期待值, 性能不足值か らの計算結果を順に Fig. 9, Fig. 10, Fig. 11 に示す.

時系列 MSS 信頼性評価手法によって求められたアべ イラビリティは, 従来の信頼性評価による信頼度よりも 低下時期が早く, より長期的な $\mathrm{RC}$ 床版の信頼性の把握 が可能となる. また, 性能期待值では, RC 床版の性能值 が要求性能值より平均してどの程度低下した状態にある か, また性能不足値では, $\mathrm{RC}$ 床版の性能值が要求性能 值より平均してどの程度不足した状態にあるかをそれぞ れ数值的に把握できることから， RC 床版の性能劣化に 対応した戦略的な補修計画の立案が可能となる。

\section{5 補修計画最適化}

\section{$5 \cdot 1$ 補修を考慮した MSS}

本研究では, 断面修復工法と表面保護工法を組み合わ せた補修のみを想定し，この補修を実施することで，腐 食した栈橋 $\mathrm{RC}$ 床版の仕上材の塩分の拡散係数とコンク リートの塩分イオン量が初期状態に戻ると考える。 また, Fig. 7 で示した栈橋 RC 床版の劣化モデルは, 補修を考 虑することで Fig. 12 のような MSS モデルとなる.

補修を考慮した栈橋 $\mathrm{RC}$ 床版の時刻 $t$ での各状態性能 の状態確率 $p_{5}(t) \sim p_{1}(t)$ は, Fig. 12 に示す確率モデルの 性能劣化と補修に対して，マルコフ過程を用いてモデル 化することで, 式 (26)の微分方程式が得られる.

補修を考慮した $\mathrm{RC}$ 床版の各性能状態の状態確率は, 初期状態 $p_{5}(0)=1, p_{4}(0)=p_{3}(0)=p_{2}(0)=p_{1}(0)=0$ で, この微分方程式を解くことで求められる.

$$
\left\{\begin{array}{l}
\frac{d p_{5}(t)}{d t}=-\lambda_{5,4} p_{5}(t)+\mu_{3,5} p_{3}(t) \\
\frac{d p_{4}(t)}{d t}=\lambda_{5,4} p_{5}(t)-\lambda_{4,3} p_{4}(t) \\
\frac{d p_{3}(t)}{d t}=\lambda_{4,3} p_{4}(t)-\left(\lambda_{3,2}+\mu_{3,5}\right) p_{3}(t) \\
\frac{d p_{2}(t)}{d t}=\lambda_{3,2} p_{3}(t)-\lambda_{2,1} p_{2}(t) \\
\frac{d p_{1}(t)}{d t}=\lambda_{2,1} p_{2}(t)
\end{array}\right.
$$

\section{$5 \cdot 2$ 補修を考慮した MSS}

本研究では, RC 床版の補修費用を Table 5 のように $1 \mathrm{~m}^{2}$ あたりの概算工事費とする。したがって, 補修 1 回 分の費用は 71,000 円 $/ \mathrm{m}^{2}$ となる。ここで, 補修費用と補 修率を組み合わせ，現在価值法を適用した 100 年間の総 補修費用を求める式 (27)を用いることで，100 年間の補

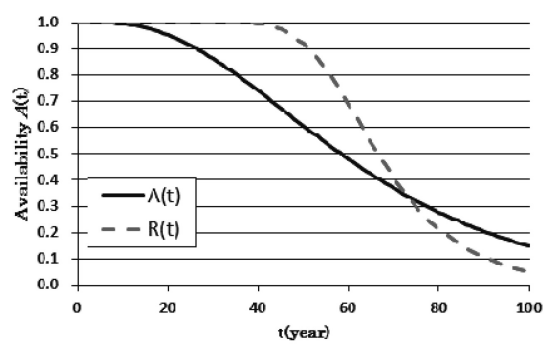

Fig. 9 Reliability $R(t)$ and Availability $A(t)$.
Fig. 10 Performance Expectation.

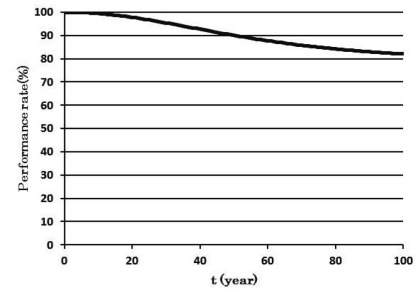

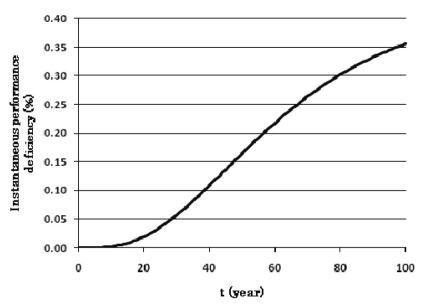

Fig. 11 Performance Deficiency.
修にかかる総費用 $C_{r}$ の算出が可能となる。ここで， $k$ は 実質利子率で, 本研究では 0.02 とする。

$$
C_{T}=\sum_{i=1}^{100} \frac{1}{(1+k)^{i}} \times 71000 \times \mu_{3,5}
$$

\section{$5 \cdot 3$ 補修計画最適化}

本研究では，信頼性に下限を設定した中で総補修費用 を最小化する補修計画を探索する。

まず従来手法により，信頼度の低下が目標信頼度 0.99 を下回らない補修戦略を想定した場合の総補修費用と目 標信頼度の結果を Fig. 13（総補修費用：棒グラフ, 信 頼度：折れ線グラフ）に示す. Fig. 13 から, 最適補修 計画はひび割れ発生から 4 年経過するたびに補修を行う 補修計画で, 総補修費用が 71,446 円 $/ \mathrm{m}^{2}$ と最小になると 予測できた。

しかし，この補修計画の評価法では，Fig. 14 に示す ように 90 年経過付近までの信頼性の低下を把握できず， また時間経過にともなう性能劣化も考慮できない，一方， 時系列 MSS 信頼性評価手法により, 期待性能值の低下 が目標期待性能値 85\%を下回らない補修戦略を想定した 場合, Fig. 15 から，最適補修計画は補修の実施間隔を 11 年とする補修計画で，総補修費用が 278,180 円 $/ \mathrm{m}^{2}$ と

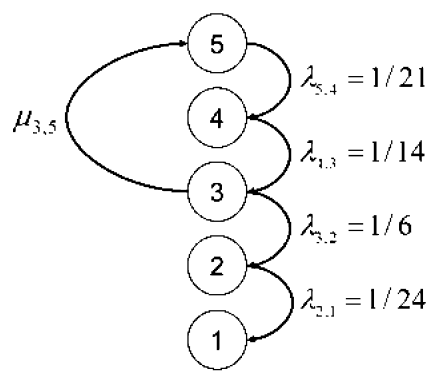

Fig. 12 State space diagram of repairable MSS of RC slab.

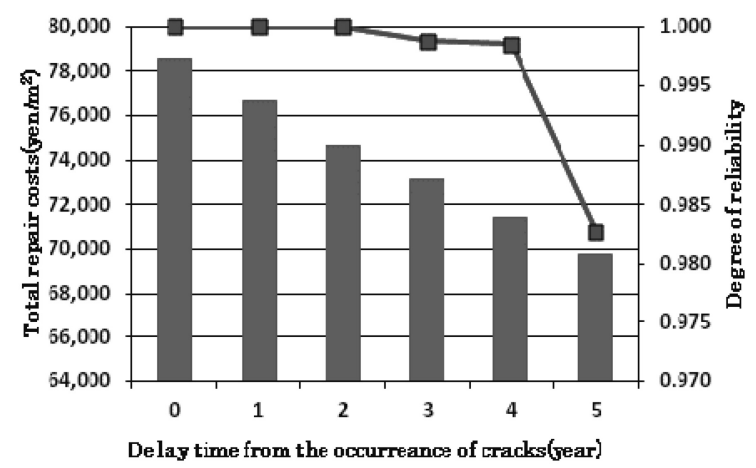

Fig. 13 Evalution of the plan at the time of repair of 100 years (Conventional approach). 


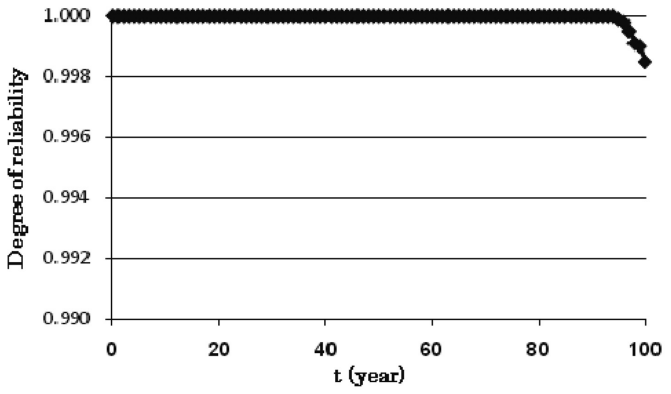

Fig. 14 Change in reliability (optimization repair plan).

最小になると予測できた。 2 つ補修戦略の目標信頼性 指標が異なるため総補修費用の低減具合に差があるが, Fig. 16, Fig. 17，Fig. 18 から，時間的な性能劣化の把握 と, 3 つの信頼性評価指標も考慮した補修計画の総合的 な評価が可能となる.

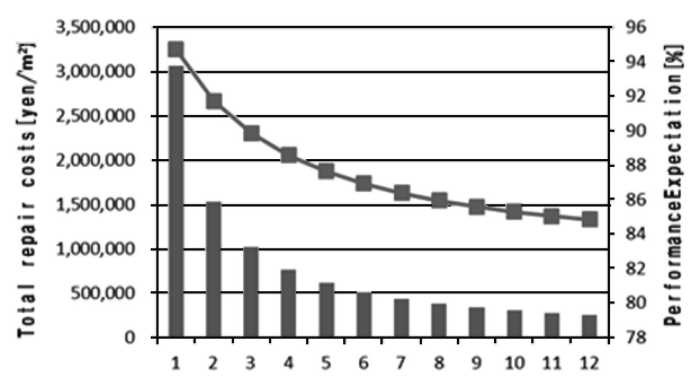

Fig. 15 Evaluation of repair program at the time of passage of 100 years (Time series MSS).

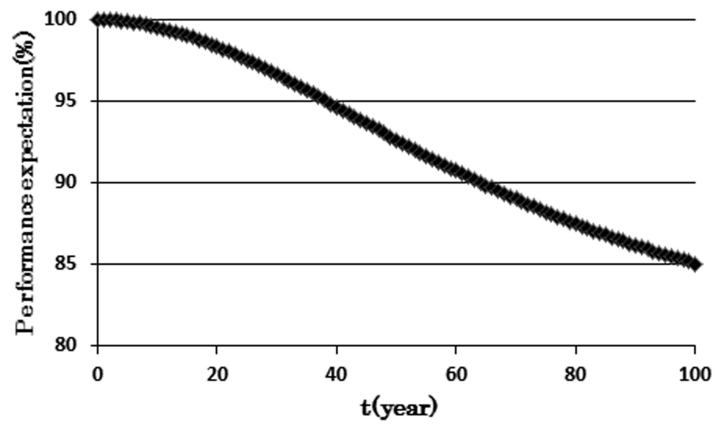

Fig. 16 Change of expectation performance value (optimization repair plan).

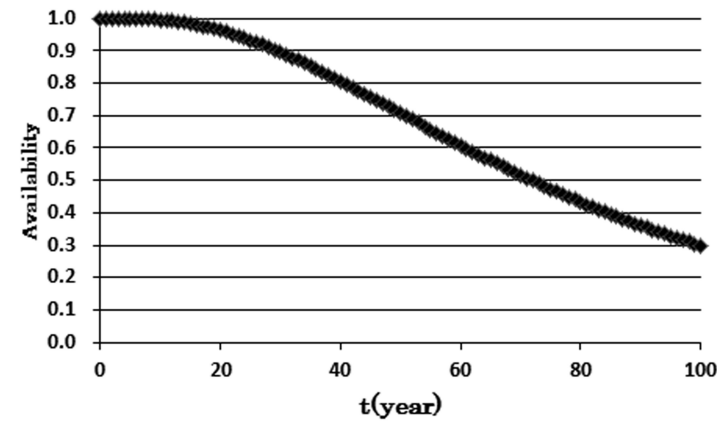

Fig. 17 Availability.

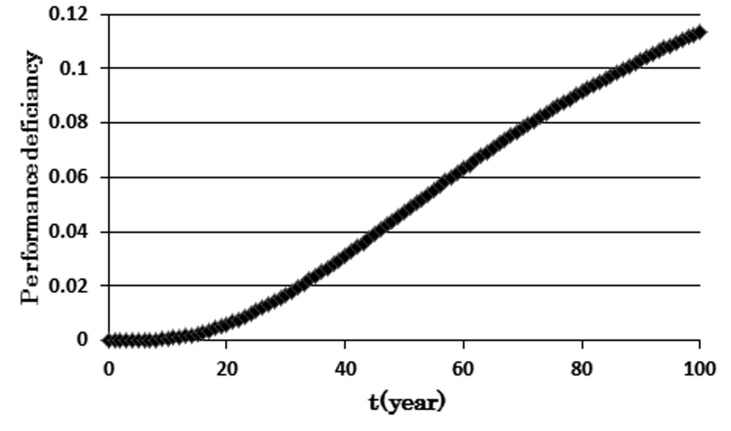

Fig. 18 Performance deficiency.

\section{6 結言}

本研究では，塩害を受ける栈橋 $\mathrm{RC}$ 床版に対して，鉄 筋が腐食した状態，コンクリートにひび割れが発生した 状態，鉄筋とコンクリートの付着力が減少し，耐力が若 干低下した状態，耐力喪失状態という時間経過とともに 多段階に変化する性能を時系列 MSS でモデル化し，信頼 性評価を行った，時系列 MSS の信頼性評価手法を用いる ことで, 特定の限界状態に注目した補修計画の安全性を 検証する従来の信頼性評価手法に比べて，より多角的な 観点から多様な信頼性の評価指標（アベイラビリティ，期 待性能值，性能不足值）による多様な評価，多様な補修 計画が可能になることを示した。

また，補修にかかる費用と信頼性評価結果から多様な 補修計画とそれに伴うライフサイクルコストを計算して 比較することで，様々な条件下で構造物の維持管理目標 に対応した補修計画の最適化が可能となることを示した。

今後は, より詳細に栈橋 $\mathrm{RC}$ 床版の塩害劣化予測を再 現するための栈橋 RC 床版 MSS モデルの拡張と，初期投 資費用と社会的損失費用を考慮したライフサイクルコス トの算出が必要であると考えている。

\section{参 考 文 献}

1) A. Lisnianski and G. Leviti, "MuHi-state system reliability assessment, optimization and applications" (2003) World Scientific

2) H. Morisaki, W. Shiraki, D. Kubota and H. Inomo, "Study on reliability assessment method of structures using multi state system”, Journal of the Society of Materials Science, Japan, Vol.57, No.3, pp.27-284 (2008).

3 ) W. Shiraki, S. Yabe, H. Inomo and M. Matsushima, "Reliability evaluation of RC highway bridge pier using time series MSS”, Journal of Structural Engineering, Vol.56A, pp.197-205 (2010).

4 ) H. Nakamoto, M. Matsushima, M. Yokota and Y. Nakagawa, "Development of prediction method of deterioration of RC structure under salt attack environment”, Proceedings of the 64th Annual Conference of the Japan Society of Civil Engineers, pp.535-536 (2009).

5 ) Y. Yamamoto and M. Matsushima, "Study on prediction of repair plan optimization of RC structures using LCC” (2008). 